\title{
Nutritive value and production of yellow bristle grass (Setaria pumila) in Waikato dairy pastures: validating Farmax model assumptions
}

\author{
K.N. Tozer ${ }^{1}$, C.A. Cameron ${ }^{1}$, R.M. Greenfield ${ }^{1}$ and C.B. Glassey ${ }^{2}$ \\ ${ }^{1}$ AgResearch, Ruakura Research Centre, Hamilton 3240, New Zealand \\ ${ }^{2}$ DairyNZ, Private Bag 3221, Hamilton 3240, New Zealand \\ Corresponding author: katherine.tozer@agresearch.co.nz
}

\begin{abstract}
Yellow bristle grass is a $\mathrm{C}_{4}$ summer-active annual weed prevalent in the upper North Island. Its production and nutritive value was assessed on-farm to validate the assumptions used in a published Farmax model on the impact of yellow bristle grass. The percentage ground cover of yellow bristle grass averaged 9\% in a survey of 39 central Waikato dairy pastures assessed each February over 8 years. Yellow bristle grass dry matter content peaked in February. Herbage production of patches of yellow bristle grass was greater than patches of perennial ryegrass when assessed over one yellow bristle grass growing season. Nutritive value was lower for yellow bristle grass than perennial ryegrass over two consecutive growing seasons. Given the prevalence of yellow bristle grass in Waikato dairy pastures, its lower nutritive value and more vigorous growth than perennial ryegrass, it is likely to have a negative impact on the performance of sown pasture species. Findings support the assumptions used in the Farmax model.
\end{abstract}

Keywords invasive grass weeds, pasture performance, dairy pastures.

\section{INTRODUCTION}

Yellow bristle grass (Setaria pumila (Poir.) Roem. \& Schult.) is an annual, $\mathrm{C}_{4}$ summer-active weed prevalent in the upper North Island and coastal Taranaki dairy pastures of New Zealand. Yellow bristle grass can grow rapidly and produce seed within 6 to 8 weeks of emergence if conditions are favourable (James et al. 2009). Livestock may avoid grazing it once seed heads are present and there are concerns regarding its low nutritive value (James et al. 2009; Tozer et al. 2014). In one microsward study in central Waikato, nutritive value of yellow bristle grass was significantly lower than that of perennial ryegrass (Lolium perenne L.) between December and March by an average of 1.2 MJ ME/kg DM (Tozer et al. 2015).
Avoidance of yellow bristle grass and a reduction in pasture quality can lead to reductions in livestock performance and milk production. For example, it was estimated using a Farmax DairyPro model that an additional $\$ 343 /$ ha was required to purchase supplementary feed to maintain milk production in perennial ryegrass-based Waikato dairy pastures infested with yellow bristle grass comprising 13\% of total DM when compared to the same pastures without yellow bristle grass (Tozer \& James 2014). The model output was based on ground cover estimates of yellow bristle grass in 39 central Waikato dairy pastures over 4 years measured each February (Tozer et al. 2012) and data on the 
nutritive value of hand-sown microswards over one growing season at one location under semicontrolled conditions (Tozer et al. 2015). The abundance and nutritive value of yellow bristle grass in a pasture may vary within years, between years and between locations. Further, it cannot be assumed that the nutritive value of yellow bristle grass grown under glasshouse conditions in potting mix and transplanted into the field is the same as that of yellow bristle under grown field conditions (e.g. compare Inam-Ur-Rahim (2008) and Tozer et al. (2015)). Given this, further monitoring of yellow bristle grass abundance and collection of nutritive value data was required with the objective of increasing confidence in the assumptions on which the Farmax model output was based and to increase the reliability of the estimate of its economic impact.

This paper reports on (1) botanical composition and herbage production of three central Waikato dairy pastures from January to May 2011 to ascertain the month in which peak YBG cover occurred, (2) changes in yellow bristle grass ground cover over 8 years based on a survey of 39 Waikato dairy pastures each February, and (3) nutritive value of yellow bristle grass and perennial ryegrass in the above-mentioned three dairy pastures over two summers.

\section{MATERIALS AND METHODS \\ Botanical composition, herbage production and nutritive value}

A total of three paddocks was randomly selected on two central Waikato dairy farms infested with yellow bristle grass. Assessments were made from January to May 2011 for botanical composition and herbage production, and from January to May 2010 and 2011 for nutritive value. Paddocks were grazed five times on the first farm and six times on the second farm during the assessment period in each of the two years.

Botanical composition was assessed using the BOTANAL method prior to grazing in 20 randomly positioned $0.31 \mathrm{~m}^{2}$ quadrats in each of the three pastures. The BOTANAL method is based on a visual estimate of dry weight ranking of the species within each quadrat (Tothill et al. 1992). Young yellow bristle grass seedlings
(1-3 leaf stage) were present in December 2010 and contributed negligible DM to the sward. Assessments therefore began in January 2011.

Herbage production was determined in each of the three pastures using a rising plate meter (RPM, 50 placements in each pasture prior to each grazing). In addition, a RPM was used to assess the comparative herbage production of randomly selected monoculture patches of perennial ryegrass and yellow bristle grass (50 RPM placements for each species in each pasture prior to each grazing). The RPM was calibrated for each assessment for each species using 20 oven-dried pasture cuts ranging in pasture height (10 cuts from each of the two farms for each grass species). The correlation coefficient for the relationship between plate meter and pasture cut estimates of herbage production ( $\mathrm{t} \mathrm{DM} / \mathrm{ha}$ ) averaged 0.76 (January to March) but dropped to an average of 0.56 for April and May (averaged over both species as the relationships for both species showed similar trends).

Nutritive value was determined by cutting to ground level a tiller from 50 randomly selected yellow bristle grass and perennial ryegrass plants in each pasture prior to each grazing. Tillers were bulked for each species, oven dried at $65^{\circ} \mathrm{C}$ and sent to a commercial laboratory for near infrared reflectance spectroscopy (NIRS) analyses (Corson et al. 1999). In the first year, wet chemistry analyses for metabolisable energy and organic matter digestibility were undertaken on four samples at extremes of the ranges obtained by NIRS. As values obtained using wet chemistry were similar and highly correlated with the NIRS values, NIRS data were considered reliable and are reported below.

\section{Yellow bristle grass ground cover}

Thirty-nine paddocks were randomly selected on 12 dairy farms within $50 \mathrm{~km}$ south of Ruakura. Percentage ground cover of each species and the amount of bare ground were visually assessed in four randomly positioned $2 \times 2 \mathrm{~m}$ quadrats in each pasture by the same operator each February over 8 years (2008-2015). Results from the first 4 years of the survey have been published (Tozer et al. 2012); the whole data set is reported here to determine long-term trends. 


\section{Statistical analyses}

All analyses were performed in GenStat, $16^{\text {th }}$ edition. Data from the pasture survey were analysed with a repeated measures Residual Maximum Likelihood (REML) (Patterson \& Thompson 1971) with farm, paddock within farm and year within paddock as random effects and year as fixed effect. Herbage production and nutritive value data from the three paddocks were analysed as a randomised block ANOVA with $\mathrm{C}_{4}$ annual grass species as treatment. Herbage production and nutritive value data presented are the averages of the three pastures.

\section{RESULTS}

\section{Botanical composition}

In mid-January, yellow bristle grass content averaged $22 \%$ of total DM (Figure 1). Yellow bristle grass content peaked in February (33\% of total DM). In March, yellow bristle grass was senescing and its content was similar to that in January ( $22 \%$ of total DM). In April, yellow bristle grass was present in the pastures only as senescent material and comprised 5\% of total DM. Summer grass (Digitaria sanguinalis L. Scop.) remained below $5 \%$ of total DM throughout the assessment period. Other species contributed up to $17 \%$ of total DM and comprised mainly buttercup (Ranunculus spp.), chickweed (Stellaria media (L.) Vill.) and creeping mallow (Modiola caroliniana (L.) G. Don). Perennial ryegrass ranged from 4053\% and white clover (Trifolium repens L.) from $14-30 \%$ of total DM, depending on the month.

\section{Herbage production}

Herbage production averaged over the three pastures was 1850 and $2880 \mathrm{~kg}$ DM/ha in summer (January-February) and autumn (March-May) respectively. Herbage production from patches of perennial ryegrass was less than that from patches of yellow bristle grass in both periods $(\mathrm{P}<0.05$, Table 1). This equated to herbage production being 1.3-fold greater in patches of yellow bristle grass than perennial ryegrass over the assessment period $(\mathrm{P}<0.01$, Table 1$)$.

\section{Yellow bristle grass ground cover}

When averaged over 39 Waikato dairy pastures and compared over 8 years, the ground cover of

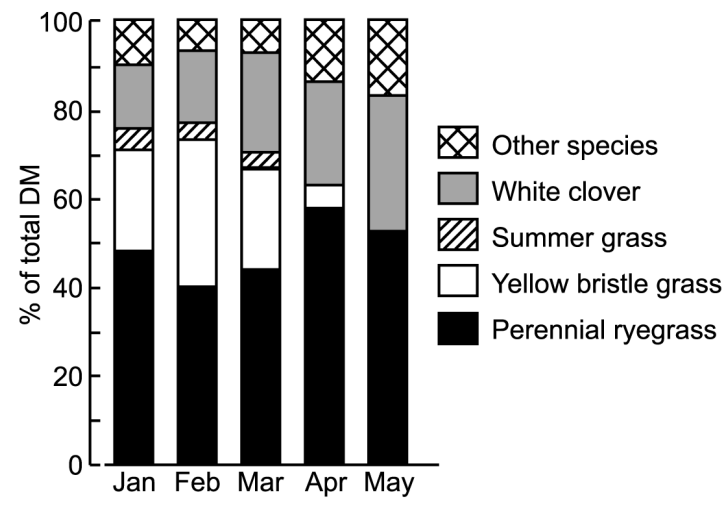

Figure 1 Botanical composition averaged across three central Waikato dairy pastures, assessed prior to grazing from January to May 2011.

yellow bristle grass peaked at approximately $12 \%$ between 2009 and 2012 and was higher than in 2008, 2013 and $2015(\mathrm{P}<0.001$, Table 2). In 2015, ground cover of yellow bristle grass was similar to that in 2008 (3-4\%). Ground cover of summer grass was highest in 2009 (16\%), other grasses in 2014 (13\%) and clover species in 2010 (24\%). Broadleaf weed ground cover remained below $12 \%$. The amount of bare ground was higher in 2008, 2013 and $2015(20-23 \%)$ than in all other years where it remained below $13 \%$.

The percentage of quadrats containing yellow bristle grass ranged from 46 to $72 \%$ and the percentage of farms on which yellow bristle grass was present ranged from 73 to $89 \%$, depending on the year.

The rainfall during summer (DecemberFebruary) at Ruakura in 2008, 2013, 2014 and 2015 was well below the long-term average (1970-2005) of $245 \mathrm{~mm}$ (Table 2).

\section{Nutritive value}

Metabolisable energy (MJ kg/DM) and crude protein (\%) levels were similar for perennial ryegrass and yellow bristle grass in summer 2010 and 2011 ( $\mathrm{P}>0.05$, Figures 2a \& 2b). The percentage of acid and neutral detergent fibre (Figures 2c \& 2d) was lower in perennial ryegrass than yellow bristle grass in summer $2010(\mathrm{P}<0.001)$ and the percentage of neutral detergent fibre also lower in perennial ryegrass 
Table 1 Herbage production (kg DM/ha) from patches of perennial ryegrass and yellow bristle grass from December to May 2011. Summer: January-February; Autumn: March-May. ${ }^{\star} \mathrm{P}<0.05,{ }^{*} \mathrm{P}<0.01$.

\begin{tabular}{lccc}
\hline Season & Perennial ryegrass & Yellow bristle grass & SED \\
\hline Summer & 1120 & 2470 & $268^{* *}$ \\
Autumn & 2810 & 3490 & $218^{*}$ \\
Total & 3930 & 5960 & $396^{* *}$ \\
\hline
\end{tabular}

Table 2 Percentage of total ground cover, percentage of quadrats with yellow bristle grass (YBG) present and percentage of farms with YBG present, based on a botanical survey of 39 dairy pastures each February. '-' not applicable. Differences between years were significantly different $(\mathrm{P}<0.001)$ for all variables analysed.

\begin{tabular}{lrrrrrrrrr}
\hline & 2008 & 2009 & 2010 & 2011 & 2012 & 2013 & 2014 & 2015 & SED \\
\hline Ground cover & & & & & & & & & \\
YBG & 4 & 11 & 11 & 12 & 12 & 7 & 9 & 3 & 2.0 \\
Summer grass & 5 & 16 & 9 & 12 & 5 & 4 & 8 & 7 & 4.6 \\
Perennial ryegrass & 56 & 42 & 36 & 39 & 48 & 49 & 49 & 55 & 3.7 \\
Other grasses & 3 & 4 & 4 & 5 & 5 & 9 & 13 & 2 & 2.6 \\
Clover & 7 & 11 & 24 & 16 & 22 & 5 & 13 & 7 & 2.2 \\
Broadleaf weeds & 4 & 9 & 12 & 11 & 5 & 3 & 4 & 3 & 1.9 \\
Bare ground & 23 & 7 & 3 & 3 & 2 & 22 & 13 & 20 & 2.1 \\
YBG presence (\%) & & & & & & & & & \\
Quadrats & 46 & 69 & 64 & 72 & 70 & 63 & 53 & 46 & - \\
Farms & 73 & 89 & 75 & 82 & 83 & 74 & 68 & 68 & - \\
& & & & & & & & & \\
Summer rainfall $^{1}(\mathrm{~mm})$ & 97 & 310 & 277 & 334 & 376 & 151 & 135 & 182 & - \\
\hline
\end{tabular}

${ }^{1}$ Summer (December - February) rainfall: based on Ruakura rainfall records.

than yellow bristle grass in summer 2011 $(\mathrm{P}<0.05)$. There was no difference between the two species in acid detergent fibre in summer 2011 ( $\mathrm{P}>0.05)$. There were significant differences between species for all parameters in autumn 2010 and 2011, with greater metabolisable energy and crude protein, and lower acid and neutral detergent fibre, in perennial ryegrass than yellow bristle grass (Figure 2). The extent of the differences between the species in autumn depended on the year for metabolisable energy, crude protein, and acid and neutral detergent fibre (interaction $\mathrm{P}<0.05$ for all components) but there were no interactions between year and species in summer $(\mathrm{P}>0.05$, data not shown).

\section{DISCUSSION}

Yellow bristle grass had a significant impact on botanical composition and quality of pasture with the highest percentage DM content of this weed occurring in February. These results confirm the choice of timing of the yellow bristle grass survey to estimate its presence during peak production. While the timing of peak cover may vary to some extent between years depending on weather patterns, high production in late summer is consistent with the summer-active nature of $\mathrm{C}_{4}$ species (Campbell et al. 1999).

The survey data demonstrate that yellow bristle grass ground cover can fluctuate significantly between years. Reasons for these fluctuations are not known although it is likely that the succession of summer droughts in the latter years (2013-2015) suppressed the growth of all vegetation, including yellow bristle grass. The absence of vegetation ground cover and the large amount of bare ground present (up to $22 \%$ of the soil surface) in 2013, 2014 and 2015 supports this. 

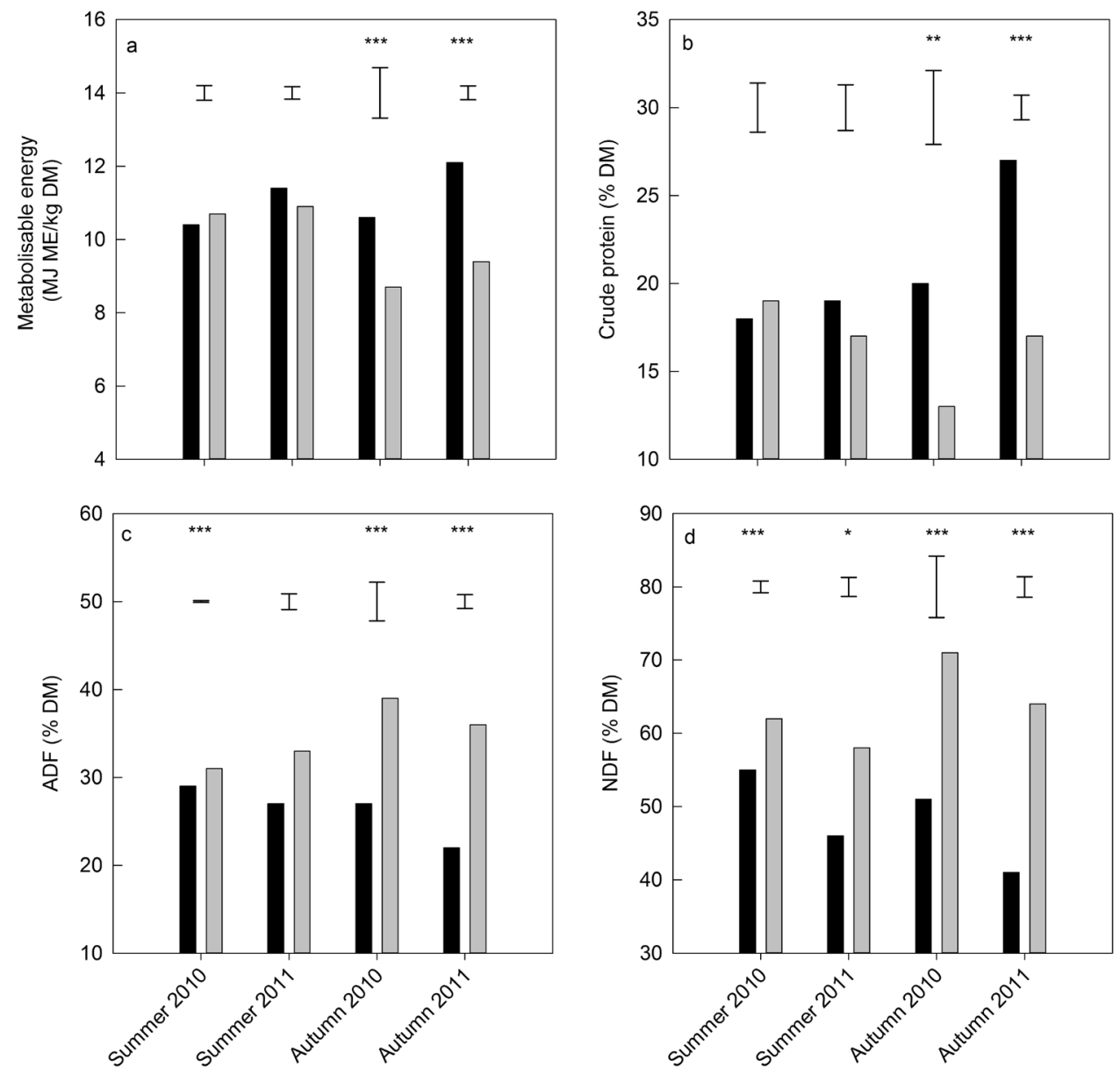

$\square$ Perennial ryegrass
Yellow bristle grass

Figure 2 (a) Metabolisable energy (MJ ME/kg DM) and (b) crude protein (\% DM), (c) acid detergent fibre $(\mathrm{ADF})$ and $(\mathrm{d})$ neutral detergent fibre (NDF) of perennial ryegrass and yellow bristle grass averaged over three Waikato dairy pastures, in summer (January- February) and autumn (March-May) 2010 and 2011. ${ }^{\star}$ denotes $\mathrm{P}<0.05$, ${ }^{\star \star} \mathrm{P}<0.01$ and ${ }^{\star *} \mathrm{P}<0.001$ for comparisons of perennial ryegrass and yellow bristle grass within each season $\times$ year combination. LSD bars are shown.

Yellow bristle grass peak ground cover in February averaged $9 \%$ over the 8 -year assessment period, which was lower than the $12 \%$ used in the Farmax model (Tozer \& James 2014). While the $12 \%$ average used in Farmax may lead to an overestimate of yellow bristle grass impact, summer grass should be taken into account as it has a similar nutritive value to yellow bristle grass (Tozer et al. 2015) and it comprised an average of $8 \%$ of ground cover during the assessment period. The $12 \%$ ground cover value for yellow bristle grass used in Farmax may therefore lead to an underestimate of the impact of key $\mathrm{C}_{4}$ annual grass weeds on dairy farm profit given the similar nutritive values of yellow bristle grass and summer grass and this should be take into account by the modellers in the model set up. Data collected here imply that yellow bristle 
grass is more vigorous than perennial ryegrass in summer and autumn, given the greater herbage production of patches of yellow bristle grass than perennial ryegrass over those seasons. If so, yellow bristle grass is likely to suppress the growth and recovery of perennial ryegrass and white clover during autumn when they are recovering from the effects of heat and moisture stress over summer. The extent of the competition between sown species and yellow bristle grass would depend on the extent to which yellow bristle grass was present, which has varied substantially between years. This suggestion of suppression of sown species by yellow bristle grass is consistent with findings from a Waikato field study in which there was a trend towards a lower DM content of sown species in late autumn and early winter in swards infested with yellow bristle grass than in swards that were free of yellow bristle grass (James et al. 2013).

The nutritive value of yellow bristle grass, as measured by its metabolisable energy, crude protein and fibre contents, remained lower than that of perennial ryegrass in at least one of the two summers and in both autumns. The extent to which its nutritive value declined in autumn depended on the year, indicating that its impact on pasture nutritive value may be worse in some years than others. The metabolisable energy of yellow bristle grass dropped to approximately $8 \mathrm{MJ} \mathrm{ME} \mathrm{kg} / \mathrm{DM}$ by the end of the assessment period, which is consistent with it being present as senescent material in March and April. These nutritive values are consistent with those used in the Farmax model and provides assurance that the model assumptions regarding nutritive value are reliable (Tozer \& James 2014).

The greater dry matter production of yellow bristle grass than perennial ryegrass may partly compensate for its lower nutritive value, if it is assumed that livestock do not avoid yellow bristle grass. While there is anecdotal evidence of avoidance after seed head emergence, monitoring of pastures before and after grazing by dairy cattle has demonstrated that livestock will graze yellow bristle grass with seed heads under a typical dairy grazing regime (James et al. 2009; Tozer et al. 2014).
Given the data presented in this paper on the prevalence, lower nutritive value and vigorous growth of yellow bristle grass when compared to perennial ryegrass, concerns regarding this weed are warranted. Assumptions regarding the nutritive value of yellow bristle grass used in the Farmax DairyPro model are robust although there have been fluctuations in yellow bristle grass prevalence over the last 8 years. As summer grass is also prevalent in pastures and as it is similar in nutritive value to yellow bristle grass, the Farmax model could be expanded to include both yellow bristle grass and summer grass with the assumption that both species are grazed.

\section{ACKNOWLEDGEMENTS}

Thanks to AgResearch and the Sustainable Farming Fund (L12-019) for funding this project and to the many farmers in the Yellow Bristle Grass Action Group who assisted with making their farms available and thoughts known.

\section{REFERENCES}

Campbell BD, Mitchell ND, Field TRO 1999. Climate profiles of temperate $\mathrm{C}_{3}$ and subtropical $\mathrm{C}_{4}$ species in New Zealand pastures. New Zealand Journal of Agricultural Research 42: 223-233.

Corson DG, Waghorn GC, Ulyatt MJ, Lee J 1999. NIRS: Forage analysis and livestock feeding. Proceedings of the New Zealand Grassland Association 61: 127-132.

Inam-Ur-Rahim, Sultan JI, Yaqoob M, Nawaz H, Javed I, Hameed M 2008. Mineral profile, palatability and digestibility of marginal land grasses of trans-Himalayan grasslands of Pakistan. Pakistan Journal of Botany 40: 237-248.

James TK, Tozer KN, Rahman A 2009. Yellow bristle grass: a recent weed incursion in Waikato dairy pastures. Proceedings of the New Zealand Grassland Association 71: 39-42.

James TK, Rahman A, Dowsett CA, Trolove MR 2013. Fenoxaprop for control of yellow bristle grass in pasture and its efficacy on other $\mathrm{C}_{4}$ grasses. New Zealand Plant Protection 66: 118-123. 
Patterson HD, Thompson R 1971. Recovery of inter-block information when block sizes are unequal. Biometrika 58: 545-554.

Tothill JC, Hargreaves JNG, Jones RM, McDonald CK 1992. BOTANAL: a comprehensive sampling procedure for estimating pasture yield and composition. I. Field sampling. Tropical Agronomy Technical Memorandum. CSIRO, Division of Tropical Crops and Pastures, St. Lucia, Brisbane, Australia. 24 pp.

Tozer KN, James TK 2014. Modelling the economic impact of yellow bristle grass (Setaria pumila) on a Waikato dairy farm. Proceedings of the Fifth Australasian Dairy Science Symposium, Hamilton, New Zealand. Pp. 255-258.
Tozer KN, Cameron CA, James TK 2012. Changes in yellow bristle grass (Setaria pumila) incidence in Waikato dairy pastures over 4 years. New Zealand Plant Protection 65: 54-58.

Tozer KN, Miller FM, Cameron CA 2014. Yellow bristle grass presence in two key New Zealand dairy regions: trends in pasture infestations and roadside spread. Proceedings of the 19th Australasian Weeds Conference, Hobart, Tasmania. Pp. 243-247.

Tozer KN, Cameron CA, Matthews L 2015. Grazing defoliation and nutritive value of Setaria pumila and Digitaria sanguinalis in Lolium perenne-based swards. Crop and Pasture Science 66: 184-191. 